\title{
Management of the severely head injured patient
}

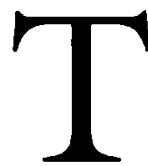

RAUMA continues to be a leading cause of mortality and morbidity in Canada. ${ }^{1}$ Traumatic brain injury (TBI) is the major contributor to traumatic deaths and disability. The impact of TBI is further emphasized because it is the leading cause of death and disability in the young, ${ }^{2}$ with potential effects for, many years. The importance of mild and moderate TBI has been increasingly recognized; this review will focus on severe TBI.

Severe TBI is characterized by a wide range of injury mechanisms leading to a similarly wide range of pathophysiological mechanisms. ${ }^{3-5}$ The common clinical picture is of coma (severe TBI is defined as a postresuscitation Glasgow Coma Scale of $3-8$ ). The outcomes range from death or vegetative state (approximately $41 \%$ ) to severe and moderate disability ( $16 \%$, $16 \%$ ) or good outcome $(27 \%)$. Recent evidence suggests that even genetic differences may exert an effect on outcome. ${ }^{6}$

Not surprisingly, few clinical trials of specific pharmacotherapy have demonstrated a beneficial effect in this group of patients who are usually enrolled into studies by the common feature of clinical coma. This is despite numerous promising laboratory studies of mechanisms and neuroprotection. ${ }^{7}$ Nevertheless, there has been a steady and important improvement in the survival of patients in the control arms of TBI clinical studies over the last two decades. ${ }^{8}$ It is generally believed that this improved mortality is a direct result of general and specific improvements in resuscitation and critical care. It is during this period, and in regard to these aspects of clinical care that the anesthesiologist is likely to be most involved. Previously, it was not uncommon for caregivers to perceive that the outcome of patients was determined at the time of impact. However, attention to improvement in the acute care of TBI victims may change their outcome from those experienced two decades ago to those in closely monitored control arms of major trials.

The approach to care of the severe TBI patient varies widely. In an effort to rationalize the approach and to try to determine which factors had improved the outcome of TBI, a systematic evidence-based set of practice guidelines was developed. ${ }^{9}$ Not only is this an excellent review of the care of TBI patients, it evaluates the level of evidence available to support much of our therapy. In many cases it is surprising how little there is.

The outcome of severe TBI is most strongly dependent on admission GCS and age. Several human studies suggest that the next most important determinants include the presence of episodes of persistent hypotension and hypoxia. ${ }^{10}$ The pathophysiology of adequate oxygen delivery is a dominant theme regarding different aspects of acute care. Achieving this goal is not always straightforward.

\section{Resuscitation}

One of the first tasks of acute resuscitation of the trauma victim involves airway management. Indications for intubation in severe TBI include inability to maintain and protect the airway, but may also include inadequate ventilation, the need to hyperventilate, hemodynamic instability and the need for imaging and surgery. The relatively common co-existence of cervical spine injury makes attention to this an ever present priority. Hemodynamic stability is similarly ranked as a priority when intubating. These priorities should not be compromised in an attempt to prevent a rise in intracranial pressure (ICP). The prompt maintenance of oxygenation and carbon dioxide control should be a priority above pharmacotherapy aimed at ICP control.

While hemodynamic stability is a principle in the approach to any trauma patient it has particular importance in TBI patients. Evidence of worse outcome following severe TBI with systolic pressures below $90 \mathrm{mmHg}^{10,11}$ and with cerebral perfusion pressures (CPP) below $70 \mathrm{mmHg}^{12}$ have led to the recommendation that these pressures be kept higher. In general, this is best achieved through intra-vascular volume replacement. However, some authors recommend temporary alpha-agonist use to achieve these goals while resuscitation proceeds. ${ }^{12}$ 
Both isotonic crystalloid and colloid are appropriate fluid choices in severe TBI. The tight junctions in an intact blood brain barrier result in the total osmolarity being the determining index of water movement into the interstitium of the brain. Because the larger pores in systemic endothelium are permeable to ions, the oncotic pressure (the portion of osmotic pressure attributable to large proteins) becomes the effective osmotic pressure in the periphery. While large volumes of infused crystalloid dilute oncotic pressure and result in systemic edema, total osmolarity will change little and, thus, does not generally result in brain edema. However, hypotonic solutions will affect water movement into the brain and should be avoided. The use of hypertonic saline solutions has been advocated because of a rapid resuscitation of CPP and a possible decrease in brain edema in severe TBI. Caution must be employed with the use of hypertonic solutions because of possible fluid overload and lung edema. Glucose containing solutions have been recommended against because, in brain ischemia and trauma, patients with higher blood glucose have worse neurological outcome. There is insufficient evidence to prove that lowering blood glucose acutely has an impact on outcome.

Raised ICP may be evident during the resuscitation period either through evidence of clinical complications (progressive coma, pupillary dilation) or through imaging features. Surgical intervention may be indicated but, in the meantime, other manoeuvres should be employed to lessen the consequences of raised ICP (herniation and insufficient CPP). These include raising the head of the bed to $15-30^{\circ}$, ensuring no obstruction to venous drainage, modest hyperventilation $\left(\mathrm{PCO}_{2} 28-32 \mathrm{mmHg}\right.$ ) and the use of mannitol. Routine use of hyperventilation is not indicated and should only be employed if there is evidence of raised ICP. Routine hyperventilation may reduce cerebral blood flow in this group of patients, many of whom may not suffer raised ICP but who have a high incidence of secondary ischemic brain injury. ${ }^{13}$

\section{Perioperative Period}

Patients suffering TBI frequently require emergency surgery for intracranial reasons (ICP monitor, cerebrospinal fluid drain, evacuation of hematoma) or for associated systemic injuries. Transfer of patients with severe TBI to neurosurgical centres seems, at first, to represent the priority. However, stabilization (including surgical resuscitative measures), the avoidance of hypotension, hypoxia and hypercarbia and the use of mannitol when indicated should precede transfer. Because of concern regarding the importance of avoiding hypotension in TBI, ${ }^{11}$ debate frequently arises about the timing of surgery that may involve considerable blood loss such as open reduction of long bone fractures. Despite demonstrating increased hemodynamic instability intraoperatively, ${ }^{14}$ it is difficult to demonstrate an impact on outcome ${ }^{15}$ in this specific example.

For severe TBI, clinical examination may not be useful for monitoring evolving intracranial events. However, the prospect of a long anesthetic for other system surgery raises concern about lack of ongoing neurologic examination. Therefore, prolonged surgery even in the presence of moderate head injury may be an indication for insertion of an ICP monitor. The use of intra-arterial catheters is justified on the basis of severe TBI alone: The use of continuous jugular venous oximetry has been advocated as a guide to adequate oxygen delivery to the injured brain. ${ }^{16}$ Alternatively, a retrograde jugular catheter may be placed (in much the same fashion as inserting a central line) into the jugular bulb for intermittent oxygen saturation monitoring. A widening difference between oxygen content in the arterial blood and the jugular bulb sample indicates increasing oxygen extraction in response to inadequate delivery. This should trigger a corrective manoeuvre such as lessening the degree of hyperventilation, increasing the cerebral perfusion pressure or increasing the oxygen content of arterial blood.

The choice of anesthetic agent should be influenced by the effect on cerebral blood flow, through important determinants such as cerebral blood volume, response to carbon dioxide tension, ICP and CPP. Isoflurane has the theoretical advantages of suppressing metabolism, and having the least upward impact on cerebral blood flow and ICP. Caution with this agent is advised when ICP is a problem. Nitrous oxide may raise cerebral blood flow inappropriately and increase ICP. The cost benefit ratio of nitrous oxide has been questioned in severe TBI. ${ }^{17}$ Intravenous agents are generally safe and advised with the possible exception of alfentanil and sufentanil which may raise cerebral blood flow and ICP. ${ }^{18,19}$ The use of propofol infusion in doses that do not precipitate hypotension has gained popularity. This has the theoretical advantage of diminishing the incidence of seizures and facilitating earlier postoperative clinical assessment than other intravenous agents.

\section{Intensive Care Unit}

The goal in the management of the severely head injured patient in the intensive care unit is to minimize secondary injury. The injury that occurs during the 
first several days following TBI includes contributions from evolving axonal injury, ${ }^{20}$ progressive inflamma$\operatorname{tion}^{21}$ and ischemic or hypoxic injury. It is the minimization of this last injury mechanism that has become the focus of clinical efforts. Episodes of this secondary injury continue through the first several days, as evidenced by multi-modal monitoring. In general terms there are three strategies, parts of which are complementary.

The first emphasizes the importance of cerebral perfusion pressure. ${ }^{12}$ This approach emphasizes the need to maintain CPP above $70 \mathrm{mmHg}$, even with the use of vasopressors if necessary. The importance of CPP is emphasized and the use of hyperventilation, in general, is minimized. The management of ICP, per se, is not as important as CPP and attempts to raise CPP to sufficient levels have little adverse effects on ICP or improved it. This approach is relatively straight forward and can be employed with an arterial line and ICP monitor only. The use of this approach is supported by studies that have demonstrated improved mortality compared with historical controls. ${ }^{12}$

Another approach, aimed at the same goal, relies on measurement of jugular venous oxygen saturation. This approach emphasizes the evaluation of the saturation of jugular venous blood as the index of oxygen delivery resulting from adequate, insufficient or excess cerebral blood flow. Thus, guided by jugular saturation, manoeuvres are employed to adjust cerebral blood flow to optimal in order to avoid the direct ischemic effects of low flow, and the potential edema and increased ICP of excess flow. Modest hyperventilation is used as necessary to treat raised ICP. The rationale for this approach is supported by evidence that patients with a higher number of episodes of jugular desaturation have a worse outcome. ${ }^{22,23}$ The use of jugular venous oximetry may allow for more direct monitoring of adverse intracranial events that have oxygen delivery implications. In a recent trial comparing jugular oximetry guided hyperventilation to CPP management, the former produced better outcome. ${ }^{16}$

Thirdly, there is the "Lund" approach. ${ }^{24}$ This emphasizes the need to avoid ongoing progressive brain edema in an attempt to ensure adequate regional perfusion. This technique employs pharmacological techniques to reduce transcapillary filtration. It involves the reduction of capillary hydrostatic pressure (including controlling CPP downwards to as low as $\mathbf{5 0}$ $\mathrm{mmHg}$ if necessary), reduction of cerebral blood volume, reduction of the stress response and cerebral energy metabolism, and fluid balance with maintenance of colloid osmotic pressure. This approach has been supported by one trial comparing it with historical and comparable controls but it requires direct comparison with randomized controls before it can be widely recommended.

Beyond the approach to these intracranial physiological variables, several other patient management issues are important. There have been many advances in ventilation strategies in general. The use of positive end expiratory pressure (PEEP) or even inverse ratio ventilation will not necessarily have an adverse effect on ICP. ${ }^{25,26}$ The priority should always rest with adequate oxygenation. In order to avoid atelectasis, the use of a minimum of $5 \mathrm{cmH}_{2} \mathrm{O}$ PEEP is recommended rather than zero PEEP.

The use of modest hypothermia for $24 \mathrm{hr}$ has recently been reported as being beneficial with respect to outcome. ${ }^{27}$ The interpretation of the data has not resulted in wide recommendation for, or practice of this technique and awaits the results of a larger multicentre trial due to be reported in the spring of 1999. Similar pediatric trials have been initiated. The prospect of a therapeutic intervention such as hypothermia in TBI is eagerly anticipated because of the dearth of effective pharmacotherapy for intervention in this condition. There is much supportive laboratory evidence that hypothermia should prove useful, however this requires translation into the clinical setting.

In parallel, but somewhat lagging behind, is a growing body of laboratory evidence that mild degrees of hyperthermia are detrimental especially in ischemic brain injury as well as in models of traumatic injury. ${ }^{28,29}$ Ischemia is a major part of the brain injury that occurs following TBI. Furthermore, there are two recent reports that parenchymal brain temperature following severe TBI in humans may exceed jugular venous and rectal temperatures by as much as $1-1.5^{\circ} \mathrm{C} .^{30,31}$ Thus, low grade fevers that would otherwise be observed or evaluated over time in a standardized approach in the intensive care unit, become potentially detrimental. Indeed, it has been suggested that one of the benefits of the use of mild hypothermia may be the avoidance of low grade systemic fever ${ }^{32}$ (and thus important brain hyperthermia) in untreated patients. Despite lack of definitive human data it seems prudent at this time to use adjunctive methods to avoid fever in the early period following TBI.

The use of steroids in TBI has been studied frequently. The appeal for their use stems not only from different pathophysiological mechanisms, but also the data suggesting benefit in traumatic spinal cord injury. ${ }^{33}$ Furthermore, there is increasing evidence that TBI initiates a central inflammatory response, including astrocyte swelling, microglia activation, as 
well as margination, microcirculatory obstruction and brain parenchymal migration by white blood cells. ${ }^{21}$ Despite this, a recent meta-analysis was unable to support their routine use in severe TBI. ${ }^{34}$

In refractory raised ICP there is evidence to support the use of high-dose barbiturate therapy. Improvement in ICP and mortality has been demonstrated. ${ }^{35}$ This technique should only be employed when standard medical and surgical approaches have failed. Caution regarding hemodynamic consequences is important especially in the trauma population, in whom occult hypovolemia may be unmasked.

Nimodipine has become standard therapy after subarachnoid hemorrhage in the prevention of delayed neurological deficit. Trials of nimodipine in severe TBI failed to show improvement in outcome, but there may be some benefit in a subgroup that exhibits traumatic subarachnoid blood. ${ }^{36}$ Subarachnoid blood may trigger vasospasm and delayed neurological deficits. A surprisingly large number of TBI patients demonstrate vasospasm by transcranial Doppler and demonstrate worse clinical outcome. ${ }^{37}$ The use of nimodipine awaits evaluation in this subgroup and may be warranted in patients exhibiting subarachnoid blood. $^{38}$

The prophylaxis of seizures is often recommended during the first week in cases involving subarachnoid blood and where there has already been a seizure. There is evidence to suggest that, paradoxically, the routine use of prolonged seizure prophylaxis may lead to a higher incidence of post traumatic seizure disorder. ${ }^{39}$ Deep venous thrombosis prophylaxis is important in this group, but is usually delayed in cases involving intracranial bleeding and until repeat imaging is performed. Early nutrition has been associated with improved outcome. While some have suggested the use of parenteral nutrition, the enteral route is usually preferred. Attempts should be made to circumvent problems of gastric paresis (common in the trauma population) with jejunal feeding tubes. As TBI is associated with a catabolic state and nitrogen loss, adequate calorie delivery and at least $15 \%$ calories from protein is recommended. ${ }^{9}$

Like many other traumatic or infectious stresses, TBI results in systemic complications. There are some important distinctive features of this response in severe TBI. For example, the severity of TBI has been linked to coagulopathy. ${ }^{40}$ This may be a direct effect of neural tissue release into the circulation. Like other injuries, severe TBI can lead to the systemic inflammatory response syndrome. Acute phase reactants become elevated and lead, in part, to the catabolic state observed after TBI. A syndrome called "delayed pulmonary dysfunction" has been applied in severe TBI and is characterized by progressively abnormal blood gases, compliance, pulmonary arterial pressures and ventilation perfusion matching. Severe TBI also leads to a neuroendocrine response which is distinct from these other non-specific responses. The neuroendocrine responses are mediated via central pathways and through sympathetic outflow tracts. They include neurogenic pulmonary edema, neurogenic myocardial injury and neurogenic hypertension. The neurogenic hypertension may not necessarily reflect raised ICP. Thus, the systemic consequences of severe TBI include a range of cardiopulmonary dysfunction. These may become the dominant problems in the intensive care unit for severe TBI patients. Subsequent complications such as ventilator associated pneumonia and sedation issues often delay anticipated recovery.

\section{Summary}

The care of the severely brain injured patient presents important challenges to the anesthesiologist. The patients are often young, there is little time for preparation, there are associated injuries, the airway management may be difficult or risky to the brain or spinal cord, the outcome varies widely and it is not always possible to monitor the desired physiological variables. Furthermore, there is no single intervention or agent that has emerged as being beneficial, but the degree to which care is taken in the domain of the anesthesiologist, will have an important impact on outcome. The central themes in patient care include rapid attention to resuscitation and maintenance of adequate CPP and oxygen delivery. Careful attention to post-operative care will also affect outcome. Recognizing that the outcome may not be determined solely at the time of impact is an important concept for all who take care of these patients.

\section{References}

1 Statistics Canada, 1998. Internet Communication: www.statcan.ca

2 Choinière $R$, Rabitaille $Y$. Methodological considerations and overall profile of mortality, hospitalizations and emergency room visits. In: Beaulne $\mathrm{G}$ (Ed.). For the Safety of Canadian Children and Youth. Ottawa: Canada Communication Group-Publishing, 1997.

3 Teasdale GM, Grabam DI. Craniocerebral trauma: protection and retrieval of the neuronal population after injury. Neurosurgery 1998; 43: 723-37.

4 Gennarelli $T A$. The pathobiology of traumatic brain injury. The Neuroscientist $1997 ; 3: 73-81$.

5 McIntosh TK, Smith DH, Meaney DF, Kotapka MJ, Gennarelli TA, Grabam DI. Neuropathological seque- 
lae of traumatic brain injury: relationship to neurochemical and biomechanical mechanisms. Lab Invest 1996; 74: 315-42.

6 Teasdale GM, Nicoll JAR, Murray G, Fiddes $M$. Association of apolipoprotein $\mathrm{E}$ polymorphism with outcome after head injury. Lancet 1997; 350: 1069-71.

7 McIntosh TK, Jubler M, Wieloch T. Novel pharmacologic strategies in the treatment of experimental traumatic brain injury: 1998. J Neurotrauma 1998; 15: 731-69.

8 Bullock $R$. Mortality rates of placebo groups in severe traumatic brain injury trials. Trauma Care 1997; 7 : 16-7.

9 American Association of Neurological Surgeons. Guidelines for the management of severe head injury. New York: Brain Trauma Foundation, 1995.

10 Chesnut RM, Marshall LF, Klauber MR, et al. The role of secondary brain injury in determining outcome from severe head injury. J Trauma 1993; 34: 216-22.

11 Pietropaoli JA, Rogers FB, Shackford SR, Wald SL. The deleterious effects of intraoperative hypotension on outcome in patients with severe head injuries. J Trauma 1992; 33: 403-7.

12 Rosner MJ, Rosner $S D$, Johnson $A H$. Cerebral perfusion pressure: management protocol and clinical results. J Neurosurg 1995; 83: 949-62.

13 Skippen $P$, Seear $M$, Poskitt $K$, et al. The effect of hyperventilation on regional blood flow in head-injured children. Crit Care Med 1997; 25: 1402-9.

14 Jaicks $R R$, Cobn SM, Moller BA. Early fracture fixation may be deleterious after head injury. J Trauma 1997; 42: 1-6.

15 McKee MD, Schemitsch EH, Vincent LO, Sullivan I. The effect of a femoral fracture on concomitant closed head injury in patients with multiple injuries. J Trauma 1997; 42: 1041-5.

16 Cruz J. The first decade of continuous monitoring of jugular bulb oxyhemoglobinsaturation: management strategies and clinical outcome. Crit Care Med 1998; 26: 344-51.

$17 \mathrm{Lam} \mathrm{AM,} \mathrm{Mayberg} \mathrm{TS.} \mathrm{Use} \mathrm{of} \mathrm{nitrous} \mathrm{oxide} \mathrm{in} \mathrm{neu-}$ roanaesthesia: why bother? J Neurosurg Anesthesiol $1992 ; 4: 290-4$.

18 Albanese J, Durbec O, Viviand $X$, et al. Sufentanil increases intracranial pressure in patients with head trauma. Anesthesiology 1993; 79: 493-7.

19 Mayberg TS, Lam AM. The effect of alfentanil on cerebral blood flow velocity and intracranial pressure during insoflurane-nitrous oxide anesthesia in humans. Anesthesiology 1993; 78: 288-94.

20 Maxwell WL, Povlishock JT, Grabam DL. A mechanistic analysis of nondisruptive axonal injury: a review. J Neurotrauma 1997; 14: 419-40.
21 Holmin S, Soderlund J, Biberfeld P, Matbiesen $T$. Intracerebral inflammation after human brain contusion. Neurosurg 1998; 42: 291-9.

22 Le Roux PD, Newell DW, Lam AM, Grady MS, Winn $H R$. Cerebral arteriovenous oxygen difference: a predictor of cerebral infarction and outcome in patients with severe head injury. J Neurosurg 1997; 87: 1-8.

23 Gopinath SP, Robertson CS, Contant CF, et al. Jugular venous desaturation and outcome after head injury. J Neurol Neurosurg Psychiatry 1994; 57: 717-23.

24 Eker C, Ásgeirsson B, Grände P-O, Nordström CH. Improved outcome after severe head injury with a new therapy based on principles for. brain volume regulation and preserved microcirculation. Crit Care Med 1998; 26: 1881-6.

25 McGuire G, Crossley D, Richards J, Wong D. Effects of varying levels of positive end-expiratory pressure on intracranial pressure and cerebral perfusion pressure. Crit Care Med 1997; 25: 1059-62.

26 Clarke JP. The effects of inverse ration ventilation on intracranial pressure: a preliminary report. Intensive Care Med 1997; 23: 106-9.

27 Marion DW, Penrod LE, Kelsey SF, Obrist WD. Treatment of traumatic brain injury with moderate hypothermia. N Engl J Med 1997; 336: 540-6.

28 Dietrich WD, Alonso $O$, Halley $M$, Busto R. Delayed posttraumatic brain hyperthermia worsens outcome after fluid percussion brain injury: a light and electron microscopic study in rats. Neurosurg 1996; 38: 533-41.

29 Minamisawa $H$, Smith $M-L$, Siesjö $B K$. The effect of mild hyperthermia and hypothermia on brain damage following 5,10 , and 15 minutes of forebrain ischemia. Ann Neurol 1990; 28: 26-33.

30 Henker RA, Brown SD, Marion DW. Comparison of brain temperature with bladder and rectal temperatures in adults with severe head injury. Neurosurgery 1998; 42: 1071-5.

31 Rumana CS, Gopinath SP, Uzura $M$, Valadka $A B$, Robertson CS. Brain temperature exceeds systemic temperature in head-injured patients. Crit Care Med 1998; 26: 562-7.

32 Shapira $\Upsilon$, Artru AA. Hypothermia to improve neurologic outcome after head injury in patients (Letter). $\mathrm{J}$ Neurosurg Anesthesiol 1998; 10: 55-5.

33 Bracken $M B$, Shepard $M J$, Holford TR, et al. Administration of methylprednisolone for 24 or 48 hours or tirilazad mesylate for 48 hours in the treatment of acute spinal cord injury. Results of the Third National Acute Spinal Cord Injury Randomized Controlled Trial. National Acute Spinal Cord Injury Study. JAMA 1997; 277: 1597-604.

34 Alderson $P$, Roberts $I$. Corticosteroids in acute traumatic brain injury: systematic review of randomised con- 
trolled trials. BMJ 1997; 314: 1855-9.

35 Eisenberg HM, Frankowski RF, Contant CF. High-dose barbiturate control of elevated intracranial pressure in patients with severe head injury. J Neurosurg 1988; 69: 15-23.

36 The European Study Group on Nimodipine in Sepere Head Injury. A multicenter trial of the efficacy of nimodipine on outcome after severe head injury. $J$ Neurosurg 1994; 80: 797-804.

37 Lee JH, Martin NA, Alsina G, McArthur DL. Hemodynamically significant cerebral vasospasm and outcome after head injury: a prospective study. J Neurosurg 1997; 87: 221-33.

38 Langham J, Goldfrad C, Teasdale $G$, et al. Assessing the effect of calcium channel blockers in patients with acute traumatic brain injury on mortality and neurological disabililty (Cochrane Review). The Cochrane Library 1998: 1-9.

39 Temkin NR, Dikmen SS, Wilensky AJ, Keibm J, Cbabal $S$, Winn $H R$. A randomized, double-blind study of phenytoin for the prevention of post-traumatic seizures. N Engl J Med 1990; 323: 497-502.

40 Stein SC, Young GS, Talucci RC, Greenbaum BH. Delayed brain injury after head trauma: significance of coagulopathy. Neurosurgery $1992 ; 30: 160-5$. 


\section{Traitement du trauma- tisme crânien sévère}

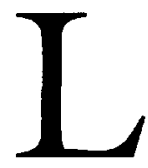

E trauma est encore la cause principale de mortalité et de morbidité au Canada. ${ }^{1}$ Le traumatisme crânien (TC) est celui qui cause le plus de décès et d'invalidité. L'impact du TC est d'autant plus important qu'il cause la majorité des décès et des cas d'invalidité chez les enfants ${ }^{2}$, et des effets potentiels qui durent des années. L'importance des TC légers et modérés a été de plus en plus reconnue; le présent article sera centré sur les TC sévères.

Le TC sévère est caractérisé par une vaste série de mécanismes lésionnels provoquant une aussi vaste série de mécanismes physiopathologiques. ${ }^{3-5}$ L'image clinique courante du TC est le coma (le TC sévère est défini par un niveau post-réanimation de $3-8$ à l'échelle de Glasgow). L'évolution possible va de la mort ou de l'état végétatif (environ $41 \%$ ) à l'invalidité sévère et modérée $(16 \%, 16 \%)$ ou à un bon rétablissement (27\%). Des preuves récentes indiquent que même des différences génétiques peuvent influer sur l'évolution d'un TC. ${ }^{6}$

Il n'est donc pas surprenant que peu d'essais cliniques sur une pharmacothérapie spécifique aient démontré un effet bénéfique dans ce groupe de patients qui sont habituellement choisis dans des études pour leur caractéristique commune de coma clinique. Et cela en dépit des nombreuses études prometteuses sur les mécanismes et sur la neuroprotection réalisées en laboratoire. ${ }^{7}$ Néanmoins, il y a eu une amélioration constante et importante de la survie des patients dans des études cliniques de groupes contrôlés sur le $\mathrm{TC}$ pendant les deux dernières décennies. ${ }^{8}$ On croit généralement que l'amélioration du taux de mortalité est le résultat direct des progrès généraux et spécifiques de la réanimation et des soins intensifs. C'est pendant cette période, et en regard de ces aspects des soins cliniques, que l'anesthésiologiste est sans doute appelé à collaborer. Auparavant, il n'était pas rare que les soignants perçoivent l'évolution des patients comme déjà déterminée au moment du trauma. Cependant, l'attention apportée à l'amélioration des soins aigus aux victimes de TC peut changer leur évolution, de la forme vécue il y a deux décennies à celle qu'on observe maintenant dans les groupes contrôlés des grands essais cliniques sous monitorage rigoureux.
La façon de traiter le patient atteint de TC sévère varie énormément. Dans le but de rationaliser le traitement et de tenter de déterminer les facteurs qui ont pu améliorer l'évolution du TC, un ensemble de recommandations de pratique clinique basées sur l'évidence scientifique a été élaboré. ${ }^{9}$ Non seulement c'est une excellente mise à jour des soins à donner aux patients victimes de TC, mais c'est aussi une évaluation de la qualité des indications disponibles pour soutenir beaucoup de nos interventions. Dans de nombreux cas, il est surprenant de constater le peu d'évidence qu'il y a.

L'évolution du TC sévère dépend surtout de l'évaluation selon l'échelle de Glasgow et de l'âge. Certaines études chez l'humain suggèrent que les autres facteurs déterminants importants sont la présence d'épisodes d'hypotension persistante et d'hypoxie. ${ }^{10} \mathrm{La}$ livraison adéquate d'oxygène est un thème dominant des soins aigus. L'atteinte de cet objectif n'est pas toujours simple.

\section{Réanimation}

Lors de la réanimation d'une victime de trauma, le contrôle des voies aériennes constitue l'une des priorités de l'intervention. Les indications de l'intubation chez les TC sévères comprennent l'impossibilité de maintenir et de protéger la perméabilité des voies aériennes, mais peuvent aussi inclure la ventilation insuffisante, le besoin d'hyperventilation, l'instabilité hémodynamique et le besoin d'imagerie diagnostique et de chirurgie. La coexistence relativement courante de lésion à la colonne cervicale fait de l'intubation une priorité encore plus importante. La stabilité hémodynamique est également prioritaire quand l'intubation est requise. Ces interventions de premier ordre ne devraient pas être compromises par des tentatives pour prévenir la hausse de pression intracrânienne (PIC). Le maintien précoce de l'oxygénation et le contrôle du gaz carbonique devraient précéder la pharmacothérapie qui vise à contrôler la PIC.

La stabilité hémodynamique est à la base du traitement de tout trauma, mais elle est particulièrement importante chez les patients TC. L'évidence de complications à la suite de TC sévère accompagné de tension systolique au-dessous de $90 \mathrm{mmHg}^{10,11}$ et de pression de perfusion cérébrale (PPC) sous $70 \mathrm{mmHg}^{12}$ ont amené à recommander que ces pressions soient main- 
tenues plus élevées. En général, la meilleure façon d'y parvenir c'est par le remplacement du volume intravasculaire. Cependant, certains auteurs recommandent l'emploi temporaire d'agonistes alpha pour atteindre ce but pendant que la réanimation est en cours. ${ }^{12}$

Les cristalloïdes isotoniques et les colloïdes sont des liquides de choix chez les TC sévères. Les jonctions occlusives de la barrière hémato-encéphalique intacte font que l'osmolarité totale devient l'indice déterminant du mouvement de l'eau dans l'interstitium cérébral. Parce que les plus grands pores de l'endothélium général sont perméables aux ions, la pression oncotique (la portion de la pression osmotique attribuable à de grosses protéines) devient la pression osmotique effective à la périphérie. Si de grands volumes de cristalloïdes perfusés diluent la pression oncotique et provoque de l'œè̀me général, l'osmolarité totale n'aura pas beaucoup d'influence et, donc, n'entraînera pas d'œdème cérébral. Cependant, les solutions hypotoniques affectent le mouvement de l'eau au cerveau et doivent être évitées. L'utilisation de solutions salées hypertoniques a été conseillée à cause de la réanimation rapide de la PPC et d'une baisse possible de l'œedème cérébral chez les TC sévères. On doit être prudent avec l'emploi de solutions hypertoniques étant donné la surcharge liquide possible et l'œedème pulmonaire. Les solutions contenant du glucose ne sont pas recommandées, car dans les cas d'ischémie cérébrale et de trauma, les patients qui présentent un taux plus élevé de glucose sanguin ont des complications neurologiques plus sérieuses. Il n'y a pas d'indications suffisantes faisant la preuve qu'une baisse agressive de glucose sanguin ait une influence sur l'évolution.

L'hypertension intracrânienne peut être évidente pendant la réanimation, soit par l'observation de complications cliniques (coma progressif, dilatation pupillaire), soit par les caractéristiques à l'imagerie. Une intervention chirurgicale peut être indiquée mais, dans l'intervalle, d'autres manoeuvres doivent être employées pour diminuer les conséquences de l'hypertension intracrânienne (hernie et PPC insuffisante). Elles comprennent l'élévation de la tête du lit de 15 $30^{\circ}$ pour s'assurer qu'il n'y a pas d'obstruction au drainage veineux, une faible hyperventilation $\left(\mathrm{PCO}_{2}\right.$ 28 - $32 \mathrm{mmHg}$ ) et l'utilisation de mannitol. L'utilisation de routine de l'hyperventilation n'est pas indiquée et devrait être réservée à la présence d'hypertension intracrânienne. L'hyperventilation de routine peut réduire le débit sanguin cérébral dans ce groupe de patients, nombre d'entre eux ne souffrent peut-être pas d'hypertension intracrânienne mais peuvent avoir une incidence élevée de lésion ischémique cérébrale secondaire. ${ }^{13}$

\section{La période périopératoire}

Les parients souffrant d'un TC ont souvent besoin d'une opération d'urgence pour des problèmes intracrâniens (monitorage de la PIC, drainage du liquide céphalo-rachidien, évacuation d'un hématome) ou pour des lésions générales associées. Le transfert des patients qui présentent un $\mathrm{TC}$ sévère vers les centres neurochirurgicaux semble, au premier abord, une priorité. Toutefois, la stabilisation (comprenant les mesures chirurgicales de réanimation), le contrôle de l'hypotension, de l'hypoxie et de l'hypercapnie et l'usage de mannitol, au besoin, doivent précéder le transfert. Étant donné l'importance d'éviter l'hypotension chez les TC, ${ }^{11}$ il y a souvent des discussions sur le moment opportun de la chirurgie qui peut comporter une perte de sang considérable comme c'est le cas de la réduction des fractures des os longs. Dans cet exemple particulier, outre l'instabilité hémodynamique peropératoire accrue, ${ }^{14}$ il est difficile de prouver un impact sur l'évolution. ${ }^{15}$

Dans le cas de TC sévère, l'examen clinique peut ne pas être utile pour le monitorage d'accidents intracrâniens évolutifs. Cependant, la perspective d'une longue anesthésie pour une opération des autres organes soulève des préoccupations au sujet de l'absence d'évaluation neurologique permanente. Pour cette raison, une opération prolongée même en présence d'une lésion intracrânienne modérée peut être une indication de l'insertion d'un moniteur de PIC. L'utilisation de cathéter artériel est justifiée seulement dans les cas de TC sévère. L'emploi continu de l'oxymétrie veineuse jugulaire a été conseillé pour servir de guide de la livraison adéquate d'oxygène au cerveau lésé. ${ }^{16}$ Comme autre solution, un cathéter jugulaire rétrograde peut être mis en place (presque de la même façon que l'insertion du cathéter central) dans le golfe de la jugulaire pour le monitorage intermittent de la saturation en oxygène. Une différence qui s'accentue entre le contenu en oxygène du sang artériel et celui de l'échantillon du golfe de la jugulaire indique la perte croissante d'oxygène en réponse à une livraison insuffisante. Cela devrait entraîner une manoeuvre correctrice comme de diminuer le degré d'hyperventilation, d'accroître la pression de perfusion cérébrale ou le contenu en oxygène du sang artériel.

Le choix de l'anesthésique doit être fait en fonction de l'effet sur le débit sanguin cérébral, d'après des déterminants importants comme le volume sanguin cérébral, la réponse à la tension du gaz carbonique, la PIC et la PPC. Théoriquement, l'isoflurane présente les avantages de supprimer le métabolisme et d'avoir l'impact ascendant le plus bas sur le débit sanguin cérébral et sur la PIC. La prudence est de mise avec ce 
médicament quand il y a un problème de PIC. Le protoxyde d'azote peut augmenter le débit sanguin cérébral de façon inappropriée et accroître la PIC. Le rapport coût-bénéfices du protoxyde d'azote a été remis en question dans les cas de TC sévère. ${ }^{17}$ Les agents intraveineux sont généralement sans risque et conseillés, sauf l'alfentanil et le sufentanil qui peuvent augmenter le débit sanguin cérébral et la PIC. ${ }^{18,19}$ L'emploi de perfusion de propofol selon des doses qui ne précipiteront pas d'hypotension est de plus en plus populaire. En théorie, cela présente l'avantage de diminuer l'incidence de convulsions et de faciliter l'évaluation postopératoire plus précoce que ce n'est le cas avec d'autres agents intraveineux.

\section{L'unité des soins intensifs}

L'objectif du traitement des traumatisés crâniens sévères à l'unité des soins intensifs est de réduire les lésions secondaires. Les lésions qui se produisent pendant les premiers jours suivant le TC comprennent la participation d'une lésion axonale évolutive ${ }^{20}$, l'inflammation progressive ${ }^{21}$ et ischémique ou la lésion hypoxique. C'est la réduction de ce dernier mécanisme lésionnel qui est devenu la principale raison des efforts cliniques. Des épisodes de lésions secondaires surviennent pendant les premiers jours comme le montre le monitorage multimodal. Généralement, il y a trois stratégies de traitement, dont certaines parties sont complémentaires.

La première met l'accent sur l'importance de la pression de perfusion cérébrale. ${ }^{12}$ Elle insiste sur la nécessité de maintenir la PPC au-dessus de $70 \mathrm{mmHg}$, même avec l'emploi de vasopresseurs au besoin. L'importance de la PPC est accentuée et l'utilisation de l'hyperventilation est en général minimisée. La prise en charge de la PIC n'est pas en elle-même aussi importante que celle de la PPC et les tentatives d'augmentation de la PPC à des niveaux suffisants n'ont que peu d'effets secondaires sur la PIC, ou ils l'améliorent. C'est une façon de procéder relativement simple, mais elle peut être employée avec un cathéter artériel et un moniteur de PIC seulement. L'emploi de cette stratégie est appuyé par des études de séries qui ont démontré l'amélioration du taux de mortalité en comparaison avec les témoins historiques. ${ }^{12}$

Une autre méthode, visant le même objectif, repose sur la mesure de la saturation en oxygène du sang de la veine jugulaire. Elle met l'accent sur l'évaluation de la saturation du sang de la veine jugulaire en qualité d'indice de la livraison d'oxygène qui résulte du débit sanguin cérébral adéquat, insuffisant ou excessif. Ainsi guidées par la saturation jugulaire, les interventions nécessaires sont faites pour ajuster le débit sanguin cérébral à son niveau optimal dans le but d'éviter les effets ischémiques directs du bas débit et l'œedème potentiel ainsi que l'accroissement de PIC du débit excessif. Une hyperventilation modeste est utilisée si nécessaire pour traiter l'hypertension intra crânienne. La logique de cette intervention vient du fait que les patients qui ont un nombre élevé d'épisodes de désaturation jugulaire connaissent une moins bonne évolution. ${ }^{22,23}$ L'usage de l'oxymétrie de la veine jugulaire peut permettre un monitorage plus direct des complications intracrâniennes qui ont des implications sur la livraison d'oxygène. Dans un essai récent comparant l'hyperventilation guidée par l'oxymétrie jugulaire à la prise en charge de la PPC, la première a produit de meilleurs résultats. ${ }^{16}$

La troisième stratégie est la méthode "Lund». ${ }^{24}$ Elle souligne la nécessité d'éviter la progression de l'œdème cérébral évolutif dans le but d'assurer la perfusion régionale suffisante. Cette méthode emploie des techniques pharmacologiques pour réduire la filtration trascapillaire. Cela implique la réduction de la pression capillaire hydrostatique (comprenant le contrôle à la baisse de la PPC jusqu'à $50 \mathrm{mmHg}$ si nécessaire), la réduction du volume sanguin cérébral, la réduction de la réponse au stress et du métabolisme énergétique cérébral et l'équilibre des liquides par le maintien de la pression osmotique colloïdale. Cette démarche a été appuyée par un essai la comparant avec des témoins historiques et comparables, mais il faudrait procéder à une comparaison directe avec des témoins randomisés avant de la recommander plus largement.

$\mathrm{Au}$ delà de la prise en charge de ces variables physiologiques intracrâniennes, il reste un certain nombre d'aspects thérapeutiques importants. Les stratégies de ventilation ont beaucoup progressé en général. L'utilisation de la pression expiratoire positive (PEP) ou même la ventilation à ratio inversé n'auront pas nécessairement d'effets secondaires sur la PIC. ${ }^{25,26} \mathrm{La}$ priorité devra toujours être la ventilation. Dans le but d'éviter l'atélectasie, l'utilisation de PEP avec 5 $\mathrm{cmH}_{2} \mathrm{O}$ est plutôt recommandée que la PEP zéro.

L'emploi d'hypothermie modeste pendant $24 \mathrm{~h}$ a été rapporté récemment comme étant bénéfique pour l'évolution. ${ }^{27}$ L'interprétation des résultats n'a pas donné lieu à d'importantes recommandations en sa faveur, ou à la pratique de cette technique, et on attend les résultats d'un grand essai multicentrique qui doivent être publiés au printemps 1999. On a amorcé des essais pédiatriques similaires. La perspective d'une intervention thérapeutique comme l'hypothermie chez les TC est vivement envisagée à cause de la pénurie de pharmacothérapie efficace dans cette situation. De nombreuses observations en laboratoire con- 
firment que l'hypothermie devrait être utile, bien que son usage doive se traduire dans le cadre clinique.

Il existe parallèlement un ensemble croissant de preuves expérimentales, dont l'importance est moins grande, qui veut que de faibles degrés d'hyperthermie soient nocifs, particulièrement dans le cas de lésion ischémique cérébrale aussi bien que dans des modèles de lésion traumatique. ${ }^{28,29}$ L'ischémie est une partie importante de la lésion cérébrale suivant le TC. Deux articles récents mentionnent que la température parenchymateuse cérébrale suivant un TC sévère chez les humains peut excéder les températures de la veine jugulaire et rectale par autant que $1-1,5^{\circ} \mathrm{C} .{ }^{30,31}$ Ainsi, une fièvre de faible degré qui serait par ailleurs observée ou évaluée régulièrement lors d'un traitement standard à l'unité des soins intensifs, devient possiblement préjudiciable. Évidemment, on a évoqué que l'un des avantages de l'utilisation d'une légère hypothermie pouvait être d'éviter une légère fièvre générale ${ }^{32}$ (donc, une hyperthermie cérébrale importante) chez les patients non traités. Malgré le manque de données concluantes pour les humains, il est prudent actuellement d'utiliser des méthodes adjuvantes pour éviter la fièvre pendant la période qui suit le TC.

On a souvent étudié les stéroïdes en rapport avec le TC. L'attrait qu'ils suscitent provient non seulement de différents mécanismes physiopathologiques, mais aussi de données qui suggèrent des bénéfices dans les cas de lésion traumatique de la colonne vertébrale. ${ }^{33}$ En outre, il y de plus en plus d'indices que le TC pourrait amorcer une réponse inflammatoire centrale, incluant le gonflement des astrocytes, l'activation de la microglie, aussi bien que la margination, l'obstruction microcirculatoire et la migration du parenchyme cérébral par les leucocytes. ${ }^{21}$ En dépit de cela, une méta-analyse récente n'a pu encourager l'utilisation de routine des stéroïdes chez les TC sévères. ${ }^{34}$

Dans l'hypertension intra crânienne réfractaire, il y a des indications pour l'usage de fortes doses de barbituriques. On a démontré une amélioration de la PIC et du taux de mortalité. ${ }^{35}$ Cette technique ne devrait servir qu'en cas d'échec des méthodes médicales et chirurgicales standards. La prudence est importante en regard des conséquences hémodynamiques, surtout chez les traumatisés chez qui l'hypovolémie peut être démasquée.

La nimodipine est devenue la thérapie standard à la suite d'hémorragie sous-arachnoïdienne dans la prévention du déficit neurologique à retardement. Des essais de nimodipine chez les TC sévères n'ont pas réussi à montrer une amélioration de l'évolution, mais il y a peut-être certains bénéfices pour ceux qui présentent un saignement traumatique sous-arachnoï- dien. ${ }^{36}$ Le sang sous-arachnoïdien peut provoquer un vasospasme et retarder les déficits neurologiques. Étonnamment, un grand nombre de patients TC démontre un vasospasme à l'examen Doppler transcrânien et une moins bonne évolution. ${ }^{37}$ L'usage de la nimodipine attend l'évaluation de ce sous-groupe et pourrait être justifié chez les patients qui présentent du sang sous-arachnoïdien. ${ }^{38}$

La prophylaxie des convulsions est souvent recommandée pendant les premières semaines dans les cas de sang sous-arachnoïdien et dans les cas où il $\mathrm{y}$ a déjà eu une crise. Des indices laissent croire que, paradoxalement, l'usage prolongé systématique de prophylaxie des convulsions peut conduire à une plus grande incidence de convulsions post-traumatiques. ${ }^{39}$ La prévention de la thrombose veineuse profonde est importante dans ce groupe, mais elle est habituellement retardée dans les cas de saignements intracrâniens et jusqu'à ce que des tests d'imageric répétés aient été réalisés. La nutrition hâtive a été associée à de meilleurs résultats. Même si certains ont proposé l'alimentation parentérale, la voie entérale est généralement préférée. On devrait tenter de circonvenir aux problèmes de parésie gastrique (commun chez les traumatisés) à l'aide de sondes d'alimentation jéjunales. Comme le TC est associé à un état catabolique et à la perte d'azote, la livraison calorique adéquate, comprenant au moins $15 \%$ des calories provenant des protéines, est recommandée. ${ }^{9}$

Comme beaucoup d'autres déséquilibres traumatiques ou infectieux, le TC provoque des complications généralisées. Il y a quelques caractéristiques distinctives importantes de cette réaction chez les TC sévères. Par exemple, la sévérité du TC a été liée à la coagulopathie. ${ }^{40} \mathrm{Ce}$ qui peut être un effet direct de la libération de tissu nerveux dans la circulation. Comme d'autres lésions, le TC sévère peut mener à un syndrome de réaction inflammatoire généralisée. Les réactants de phase aiguë s'élèvent et provoquent, d'une part, l'état catabolique observé après le TC. Un syndrome appelé «dysfonctionnement pulmonaire retardé» s'applique au TC sévère et est caractérisé par des changements progressivement anormaux des gaz du sang, de la compliance, des pressions artérielles pulmonaires et de l'équilibre du rapport ventilation/perfusion. Le TC sévère conduit aussi à une réponse neuroendocrine qui est distincte des autres réponses non spécifiques. Les réponses neuroendocrines se produisent par la médiation de voies centrales et passent ensuite par les voies de décharge sympathiques. Elles comprennent l'œdème pulmonaire neurogénique, la lésion myocardique neurogénique et l'hypertension neurogénique. L'hypertension neurogénique peut ne pas refléter nécessairement l'hypertension intracrâ- 
nienne. Ainsi, les conséquences générales du TC sévère comprennent une série de dysfonctionnements cardiopulmonaires. Ils peuvent devenir les problèmes dominants des TC sévères à l'unité des soins intensifs. Les complications subséquentes comme la pneumonie associée à la ventilation et les difficultés de sédation retardent souvent la récupération attendue.

\section{Sommaire}

Le traitement des patients atteints de lésions cérébrales sévères représente un important défi pour les anesthésiologistes. Les patients sont souvent jeunes, il n'y a pas beaucoup de temps pour se préparer à intervenir, il y a des lésions associées, l'intubation peut être difficile ou risquée pour le cerveau ou la moelle épinière, l'évolution est très variable et il n'est pas toujours possible de procéder au monitorage des variables physiologiques désirées. En outre, on n'a pu prouver l'existence d'une intervention ou d'un médicament unique qui soit avantageux, mais le degré de prise en charge du traitement par les anesthésiologistes aura une influence importante sur l'évolution du patient. Les thèmes centraux du traitement comprennent une réanimation rapide et le maintien de la PPC et de la livraison d'oxygène adéquates. Une attention spéciale aux soins postopératoires aura aussi une influence sur l'évolution. Reconnaître que l'évolution peut ne pas être déterminée au moment de l'impact est un concept important pour tous ceux qui prennent soin de ces patients.

\section{Références}

(Voir page R38) 